\title{
Violencia institucional/colonial en nombre del padre...
}

\author{
Margarita Kalfio Montalva y Andrea SalazarVega ${ }^{1}$ \\ Universidad de Chile \\ andreapingen@gmail.com \\ maigokalfio@gmail.com
}

Cuando se inició el proceso de construir colectivamente este dossier -al calor de la oleada de allanamientos a comunidades mapuche, tras la muerte de dos terratenientes en Vilcún a principios de año-, pensábamos en la posibilidad de develar los orígenes de la violencia institucional ejercida contra el pueblo mapuche. Observamos que este tipo de violencia es posible de hallar en diversos ámbitos: en la escuela, centros de salud, la justicia, dependencias policiales, etc. Aunque está generalizada y extendida, los actos de violencia institucional se cometen en la clandestinidad y con prácticas de encubrimiento. Sería invisible si no fuera por las denuncias de las víctimas, de sus familiares o por el accionar de las organizaciones sociales.

Se hace una diferencia respecto a violencia institucional contra las mujeres, comprendida como "los actos $\mathrm{u}$ omisiones de las y los servidores públicos de cualquier orden de gobierno que discrimine o tengan como fin dilatar, obstaculizar o impedir el goce y ejercicio de los derechos humanos de las mujeres así como su acceso al disfrute de políticas públicas destinadas a prevenir, atender, investigar, sancionar y erradicar los diferentes tipos de violencia." ${ }^{2}$.

Al seguir desenredando los nudos de la violencia, en cada hebra fuimos notando los matices de racismo y discriminación que han teñido las relaciones entre mapuche y chilenxs a lo largo de la historia. En conversaciones con el académico Luis CárcamoHuechante acerca de la actual situación mapuche, se entrecruzó la 
noción de colonialismo, para él "las violencias coloniales se ejercen con tal de darle continuidad a un sistema de dominación, despojo y vejación de carácter estructural, que somete a todo un pueblo y adquiere formas públicas y domésticas, macro y micropolíticas, simbólicas y cotidianas, jurídicas y territoriales, invisibilizadas y silenciadas".

Se trata de violencias que se manifiestan en la evidencia pública de la represión policial militar hoy o en los contextos cotidianos, en el racismo, en los trabajos, en las ciudades, en el campo, en las aulas, en los hospitales, en las relaciones de géneros y prácticas patriarcales, en los lenguajes, en los entornos visuales y acústicos en que habitamos; más aún, también es constantemente reproducida por la sociedad mapuche, comenta Cárcamo-Huechante.

Remontándonos al siglo XIX, un argumento que posibilitó la ocupación del país mapuche fue de carácter ideológico. El pensamiento ilustrado y liberal de entonces, imbuido de las ideas del positivismo, consideraba a lxs mapuche como pertenecientes a una raza inferior y bárbara. “Ocupar la Araucanía era asegurar el triunfo de la civilización sobre la barbarie, de la humanidad sobre la bestialidad. Chile se unía a una cruzada universal, que el hombre debería agradecer en el futuro." (Pinto, 1996, 295).

El poeta, dramaturgo y pensador martiniqueño Aimé Césaire, establece lúcidamente que "la colonización [...] deshumaniza aun al más civilizado de los hombres [...] el colonizador que, para irse haciendo la idea, se habitúa a ver en el otro a la bestia y a tratarlo como bestia, tiende objetivamente a transformarse él mismo en bestia".

En el caso de Chile, uno de los que dirigieron la empresa de ocupación del territorio mapuche, la llamada "Pacificación de la Araucanía", fue el coronel Cornelio Saavedra. En una de sus declaraciones contenidas en el Informe de la Comisión Verdad Histórica y Nuevo Trato con los Pueblos Indígenas (2008), resuenan las palabras de Césaire con respecto a la deshumanización que vivencian los colonizadores:

Como los salvajes araucanos, por la calidad de los campos que dominan, se hallan lejos del alcance de nuestros soldados, no queda a estos otra acción que la peor y más repugnante en 
esta clase de guerra, es decir: quemar sus ranchos, tomarles sus familias, arrebatarles sus ganados i destruir en una palabra todo lo que no se les puede quitar ${ }^{3}$.

En este nuevo escenario de despojo y radicación, la sociedad mapuche sufrió vastas transformaciones. En el caso de las mujeres, perdieron su valor social como medio de intercambio y su papel reproductivo ya no fue apreciado como en tiempos de libertad. A decir de Bengoa, "la reducción en comunidades cercenó el espacio propio de las mujeres, lo empobreció al extremo y desvalorizó sus principales funciones. Con la reducción se acabaron los intercambios políticos de mujeres para constituir alianzas" $(1992,101)$.

Junto a la radicación se abre un camino de asimilaciónintegración de la sociedad mapuche por parte de la sociedad chilena. La herramienta principal de este proceso fue la educación y su aparataje institucional de internados, escuelas misionales y reformatorios, que tendió a eliminar lo propiamente mapuche e imponer una visión católica occidental. Como consecuencia de todo esto, vemos con preocupación los resultados de un reciente estudio del Fondo de las Naciones Unidas para la Infancia (Unicef) y del Ministerio de Desarrollo Social, el cual determinó que el 89\% de los menores de edad pertenecientes a pueblos indígenas del país no habla ni entiende su lengua originaria ${ }^{4}$. Esto es grave ya que la lengua constituye el elemento cultural base de un pueblo, la herramienta a través de la cual se comunican los sentires, deseos, sueños y anhelos de un pueblo libre.

Desde su creación hace poco más de doscientos años, el Estado chileno se ha comportado distante con los pueblos originarios. Como un padre ausente pero castigador... La violencia practicada por agentes estatales, basada en la representación creada de "terroristas", producto de una ley heredera de la dictadura militar. Luego, la situación de 12 mujeres mapuche y el sobreseimiento de sus agresores en casos de violencia intrafamiliar, por dictamen del ministerio público aludiendo al artículo de la costumbre indígena del Convenio $N^{\circ} 169$ de la OIT; una mala utilización de un instrumento internacional, según establecen algunas organizaciones mapuche y no mapuche. Este tipo de reflexiones está presente en las opiniones de quienes comentan este dossier, tres dirigentas mapuche quienes 
desde su actuar político y la denuncia, afianzan el compromiso con su pueblo, en constante transformación y alerta.

\section{Notas}

1. Parte de este dossier es fruto del proyecto FONDECYT 1110086 titulado "Pluralismo cultural, pueblos originarios y Derecho Penal chileno: del Derecho Indiano a la Administración Biopolítica: Bases para una Reforma Penal Integral" cuya ejecutora responsable es la profesora de la Universidad Central de Chile, Myrna Villegas Díaz.

2. Ver: http://www.violenciagenero.unach.mx/index.php?option=com_content\&vie $\mathrm{w}=$ article\&id $=5 \&$ Itemid $=5$

3. Ver: http://bibliotecadigital.indh.cl/bitstream/handle/123456789/268/nuevo-tratoindigena.pdf?sequence $=1$

4. Ver: http://www.cooperativa.cl/noticias/pais/pueblos-originarios/nueve-de-cada10 -menores-indigenas-chilenos-no-hablan-ni-entienden-su-lenguaoriginaria/2012-01-23/144940.html 